\title{
Procesy restrukturyzacji górnictwa: Zagłębie Górnośląskie i Zagłębie Ruhry
}

\author{
Mateusz Rybarz \\ Uniwersytet Ekonomiczny w Katowicach, Wydział Ekonomii, mateusz.rybarz@edu.uekat.pl, \\ ORCID: 0000-0001-5004-5336
}

Streszczenie: Celem artykułu jest wskazanie podobieństw oraz różnic między Zagłębiem Ruhry a Zagłębiem Górnośląskim występujących podczas restrukturyzacji tych górniczych regionów. Na potrzeby badań dokonano szczegółowego przeglądu dostępnej literatury przedmiotu (zarówno w języku polskim, angielskim, jak i niemieckim) oraz wykorzystano analizę danych statystycznych. Artykuł omawia podobieństwa obu regionów $\mathrm{w}$ momencie rozpoczęcia procesu i znaczące różnice $\mathrm{w}$ czasie przeprowadzania restrukturyzacji. Realizowany w Zagłębiu Ruhry proces miał charakter przemyślanej, konsekwentnie realizowanej, długookresowej strategii, dlatego jego efekty są oceniane pozytywnie, zarówno w kontekście społecznym, jak i gospodarczym. Natomiast rozwiązania przyjęte w Zagłębiu Górnośląskim cechuje zmienność koncepcji i chaotyczność wprowadzanych rozwiązań. Niemniej jednak w obu regionach można wskazać mocne i słabe strony omawianego procesu.

Słowa kluczowe: górnictwo, restrukturyzacja, węgiel kamienny, Zagłębie Górnośląskie, Zagłębie Ruhry.

Kod JEL: O170, R110, L690.

\section{Wstęp}

Zatrudnienie w sektorze węglowym stanowi według danych za 2017 r. zaledwie $0,15 \%$ zatrudnienia w Europie, jednak sektor węglowy charakteryzuje wysoka koncentracja oraz fakt, że ma on istotne znaczenie dla poszczególnych regionów (Galgóczi, 2019, s. 19). Wraz z rozwojem i zmianami strukturalnymi gospodarek dochodzi do potrzeby restrukturyzacji, a nawet likwidacji danego sektora gospodarki. Procesy restrukturyzacyjne w ekonomii oznaczają operację 
o charakterze finansowym (restrukturyzacja kapitału, zadłużenia itp.) lub reorganizację sektora działalności gospodarczej czy też przedsiębiorstw. Restrukturyzacje regionów górniczych charakteryzują się całkowitą zmianą struktury gospodarczej danego regionu, przez co trudno przewidzieć skutki działań. Ze względu na mnogość podejmowanych decyzji, które trzeba wdrożyć w procesie restrukturyzacji regionów górniczych, w proces ten najczęściej zaangażowane jest państwo. Dzięki porównaniu procesów restrukturyzacji w Zagłębiu Górnośląskim oraz Zagłębiu Ruhry można wskazać na pozytywne działania, poprzez które w Zagłębiu Ruhry udało się zakończyć ten proces, i zastosować podobne działania w analogicznym procesie w Polsce.

Celem niniejszego artykułu jest porównanie Zagłębia Górnośląskiego i Zagłębia Ruhry w czasie procesów restrukturyzacji oraz wskazanie istotnych inwestycji strategicznych w wybranych regionach.

W opracowaniu poddano weryfikacji następującą hipotezę badawczą: oba zagłębia charakteryzowały podobne warunki w początkowym okresie procesu restrukturyzacji (m.in. powierzchnia, liczba ludności, położenie oraz struktura miejska) i dlatego powinny one w podobny sposób determinować decyzje dotyczące procesów restrukturyzacji.

Części teoretyczna i praktyczna artykułu powstały w oparciu o szeroką kwerendę literatury przedmiotu; skorzystano z materiałów źródłowych zarówno polsko-, jak i niemieckojęzycznych, dokonano także analizy porównawczej danych statystycznych dotyczących omawianych regionów.

\section{Istota, przyczyny oraz cele restrukturyzacji}

Wielowymiarowość pojęcia restrukturyzacji skutkuje brakiem ogólnej definicji. Według Bickslera i Chena „restrukturyzacja to strategia wzrostu i reorientacji gospodarki (sektora, regionu, podmiotu gospodarczego)" (Borowiecki, 2014, s. 14). Natomiast Myers określa restrukturyzację jako „strategiczny proces prowadzący do maksymalizacji wartości gospodarki i jej podmiotów" (Borowiecki, 2014, s. 14). Według Grynchyshyna (2015) restrukturyzację można interpretować jako proces adaptacji do czynników wewnętrznych i zewnętrznych; proces przejścia z jednego modelu biznesowego do innego czy też jako głęboką transformację działalności przedsiębiorstwa. Pomimo różnic wszystkie te definicje pojęcia restrukturyzacji mają jedną cechę wspólną w postaci celu, jakim jest „poprawa racjonalności i efektywności gospodarowania zasobami oraz czynnikami wytwórczymi, nadanie strukturze gospodarczej cech nowoczesności, ela- 
styczności, innowacyjności i adaptacyjności” (Żaba-Nieroda, 2018, s. 50). Przyczyny restrukturyzacji mogą być zewnętrzne (sytuacja na rynkach światowych, przemiany, zmiany trendów, zmiany prawne, regulacje) oraz wewnętrzne (problemy organizacyjne przedsiębiorstw, nadmierne zatrudnienie, nieefektywność produkcyjna). Do głównych celów restrukturyzacji mezoekonomicznej, której zmiany obejmują szczególnie strukturę oraz system zarządzania w sektorach gospodarki lub całych regionach, należą:

- zapewnienie w perspektywie krótkookresowej przetrwania przedsiębiorstwom w regionie oraz sektorom,

- w perspektywie długookresowej zapewnienie rozwoju dla regionu lub przedsiębiorstwom w sektorze,

- zapewnienie płynności finansowej,

- zwiększenie konkurencyjności poprzez budowanie przewag konkurencyjnych.

\section{Zagłębie Górnośląskie i Zagłębie Ruhry - informacje podstawowe}

Zarówno Zagłębie Górnośląskie, które w artykule rozumie się jako część polską polsko-czeskiego zagłębia węglowego obejmującego tereny Górnego Śląska oraz części Małopolski (Zagłębie Dąbrowskie oraz Zagłębie Krakowskie) ${ }^{1}$, jak i Zagłębie Ruhry, to stare zagłębia przemysłowe, które swoje powstanie zawdzięczają rewolucji przemysłowej zapoczątkowanej w XIX w. Po latach prosperity i wzrostu produkcji wskutek przemian gospodarczych i globalizacji oba regiony zostały zmuszone do restrukturyzacji. Przemiany restrukturyzacyjne w omawianych zagłębiach związane są głównie z górnictwem węgla kamiennego, jednakże jest to branża bardzo rozległa. Wraz z kryzysem kopalń wydobywających węgiel dochodzi także do kryzysu w branżach tworzących łańcuch wartości, takich jak przemysł maszynowy, stalowy czy wytwórczy. Restrukturyzacja górnictwa w tych regionach to nie tylko problem kopalń węgla, lecz całego regionu.

Omawiane regiony przemysłowe mają wiele wspólnych cech, m.in.: podobną historię gospodarczą, zbliżoną wielkością powierzchnię oraz obecność dużej liczby głębinowych kopalń węgla kamiennego. Ponadto w obu regionach

\footnotetext{
Zgodnie z informacjami z Państwowego Instytutu Geologicznego obszar obejmuje 133 udokumentowanych złóż węgla kamiennego, z których 50 jest zagospodarowanych (Jureczka \& Nowak, 2016, s. 618).
} 
na początku restrukturyzacji istniał silny przemysł metalurgiczny pomimo braku złóż żelaza w pobliżu. Złoża węgla w obu regionach stanowią jedne z największych złóż w Europie (Alves Dias et al., 2018, s. 19) - por. tabela 1. Głównym czynnikiem różniącym oba regiony, a mającym duży wpływ na procesy restrukturyzacyjne, jest struktura własnościowa. W Zagłębiu Ruhry znajdowały się głównie małe prywatne kopalnie, natomiast w Zagłębiu Górnośląskim kopalnie stanowiły i stanowią w zdecydowanej większości własność państwową ${ }^{2}$.

Poprzez silny rozwój przemysłu stalowego oraz wydobywczego od XIX w. do I połowy XX w. w obu zagłębiach inwestycje strategiczne koncentrowały się na przemyśle i zwiększaniu produkcji przemysłowej. Pomimo spadku znaczenia przemysłu ciężkiego w przededniu restrukturyzacji Zagłębie Ruhry i Zagłębie Górnośląskie miały duże znaczenie gospodarcze oraz społeczne zarówno w Niemczech, jak i w Polsce. Pod względem zaludnienia Zagłębie Ruhry tworzyło i nadal tworzy jedno z największych aglomeracji miejskich w Europie. Na Górnym Śląsku związek metropolitalny skupiający 14 miast to najgęściej zaludniony obszar w Polsce (Pudlik \& Garus, 2009) - por. tabela 1.

Tabela 1. Porównanie Zagłębia Górnośląskiego i Zagłębia Ruhry - informacje podstawowe (stan przed restrukturyzacją)

\begin{tabular}{|l|c|c|}
\hline $\begin{array}{l}\text { Glówne cechy regionów na } \\
\text { początku restrukturyzacji }\end{array}$ & Zaglębie Ruhry & Zagębie Górnośląskie \\
\hline Powierzchnia & $4400 \mathrm{~km}^{2}$ & ok. $4500 \mathrm{~km}^{2}$ w granicach Polski \\
\hline Ludność & $5,674,223(1961 \mathrm{r})$. & ok. $4,500,000$ \\
\hline Główny nośnik energii & węgiel kamienny & węgiel kamienny \\
\hline Typ kopalń & kopalnie głębinowe - podziemne & kopalnie głębinowe - podziemne \\
\hline Liczba górników & $\sim 480,000(1956$ r.) & $\sim 400,000(1990$ r.) \\
\hline $\begin{array}{l}\text { Struktura własnościowa } \\
\text { kopalń }\end{array}$ & własność prywatna & własność państwowa \\
\hline $\begin{array}{l}\text { Okres trwania restrukturyza- } \\
\text { cji }\end{array}$ & $1960-2018$ & 1990 - nadal \\
\hline Wydobycie węgla & $\sim 124$ mln ton $(1956$ r.) & $\sim 140$ mln ton (1990 r.) \\
\hline Liczba kopalń & $138(1957$ r.) & 67 (1990 r.) \\
\hline Struktura miejska & policentryczna & policentryczna \\
\hline Położenie & Nadrenia Północna-Westfalia & Śląsk, część Małopolski \\
\hline
\end{tabular}

Źródło: Na podstawie: Kuchciński (1958, s. 553); Oei et al. (2020, s. 966).

Każdy z omawianych regionów rozpoczął swoją restrukturyzację zaraz po osiągnięciu największego poziomu wydobycia w historii tych regionów (dane szczegółowe przedstawiono na rysunku 1). Za początek procesu restrukturyzacji

2 Wyjątek stanowi Przedsiębiorstwo Górnicze „Silesia”. 
w Zagłębiu Ruhry można przyjąć 1958 r., kiedy władze federalne podjęły decyzję o subsydiowaniu sektora, natomiast $\mathrm{w}$ Zagłębiu Górnośląskim nastąpił on w czasie powstania pierwszych programów rządowych dotyczących pomocy i zmian w sektorze, czyli w $1990 \mathrm{r}$.

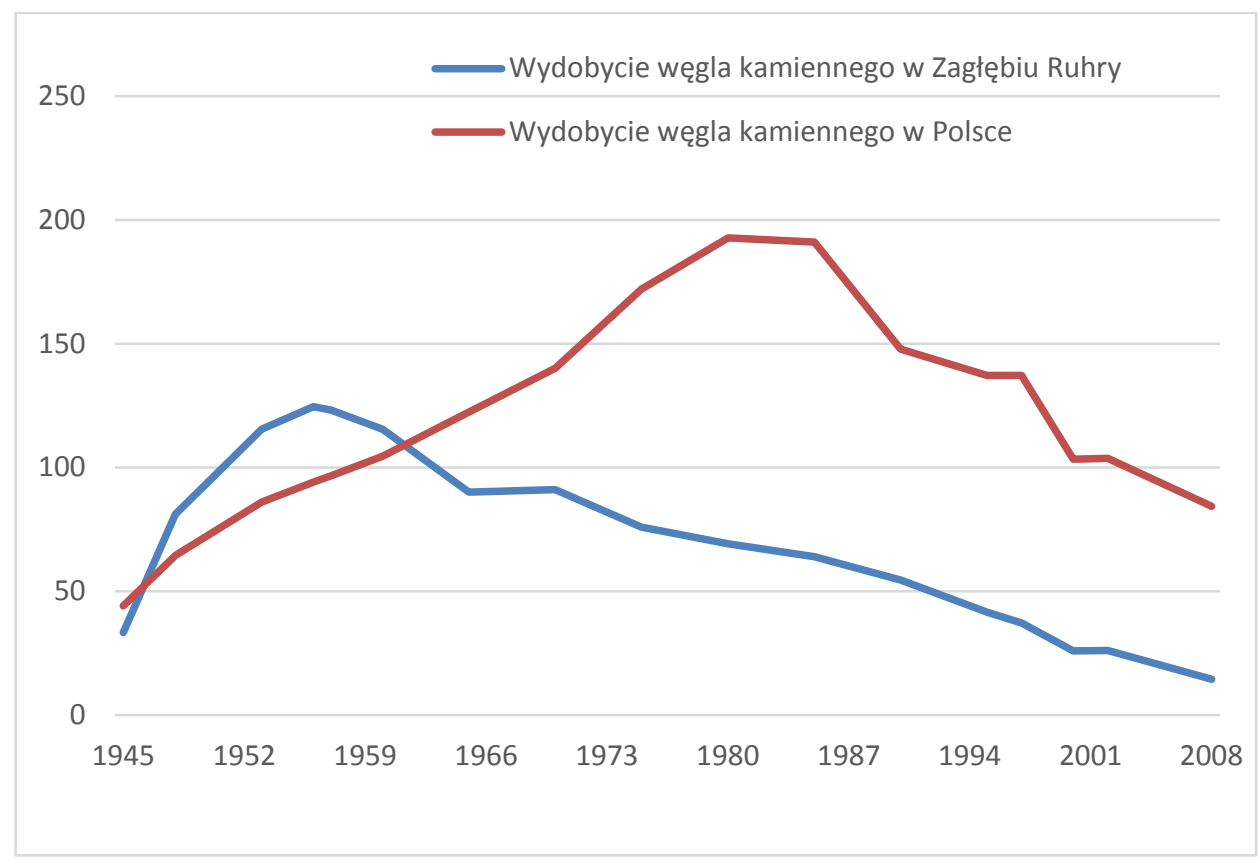

Rysunek 1. Wydobycie węgla kamiennego w Polsce i w Zagłębiu Ruhry w latach 1945-2007

Źródło: Na podstawie: Statistik der Kohlenwirtschaft E.V. (2019, s. 28); Popkiewicz (2021).

Istnieje wiele podobieństw między Zagłębiem Górnośląskim i Zagłębiem Ruhry, jeśli chodzi o początek procesu restrukturyzacji w tych regionach, $w$ tym m.in.:

- bliskość ośrodków przemysłowych (Wrocław, Kraków, Ostrawa),

- monolityczna struktura gospodarcza skoncentrowana na przemyśle ciężkim,

- system transportowy lepszy niż w pozostałej części kraju (Diagnoza systemu transportu województwa śląskiego, 2012, s. 39),

- dominacja małej liczby dużych przedsiębiorstw, słabo rozwinięty sektor małych i średnich przedsiębiorstw.

Oba regiony w okresie rozpoczęcia restrukturyzacji borykały się z wieloma problemami. Mocne i słabe strony Zagłębia Ruhry przedstawia tabela 2. 
Tabela 2. Mocne i słabe strony Zagłębia Ruhry pod koniec lat 50. XX w.

\begin{tabular}{|l|l|}
\hline \multicolumn{1}{|c|}{ Mocne strony } & \multicolumn{1}{c|}{ Słabe strony } \\
\hline $\begin{array}{l}\text { Bliskość ośrodków przemysłowych we Francji, } \\
\text { Holandii i Belgii }\end{array}$ & $\begin{array}{l}\text { Monolityczna struktura gospodarcza, koncentrująca } \\
\text { się na węglu i przemyśle ciężkim wykorzystującym } \\
\text { węgiel }\end{array}$ \\
\hline $\begin{array}{l}\text { Dobrze rozwinięty system transportowy wewnątrz } \\
\text { regionu }\end{array}$ & $\begin{array}{l}\text { Dominacja kilku dużych firm w regionie oraz mała } \\
\text { liczba słabo rozwiniętych małych i średnich firm }\end{array}$ \\
\hline $\begin{array}{l}\text { Lokalizacja blisko głównych portów morskich } \\
\text { Europy (Hamburg, Rotterdam, Antwerpia) oraz } \\
\text { lotniska we Frankfurcie nad Menem }\end{array}$ & $\begin{array}{l}\text { Słabo rozwinięty system edukacji w regionie } \\
\text { (brak uniwersytetu) }\end{array}$ \\
\hline
\end{tabular}

Źródło: Na podstawie: Oei et al. (2020, s. 973).

\section{Kolejne inwestycje strategiczne w procesach restrukturyzacji}

Zagłębie Ruhry pomogło Republice Federalnej Niemiec wyjść z kryzysu po II wojnie światowej. Jednak w latach 50. XX w. wraz ze wzrostem kosztów wydobycia, zwiększonego importu i znaczenia ropy naftowej i taniego węgla z USA oraz krajów bloku wschodniego niemiecki węgiel stracił na konkurencyjności. Rząd federalny w związku z kryzysową sytuacją w górnictwie węgla kamiennego musiał podjąć kroki mające na celu niedopuszczenie do masowego zamykania kopalń w krótkim czasie, ponieważ spowodowałoby to nagły wzrost bezrobocia $\mathrm{w}$ regionie, dotyczący nie tylko pracowników kopalń, ale także zakładów związanych z górnictwem. Pod koniec lat 60 . XX w. co dziesiąty mieszkaniec Zagłębia Ruhry był zatrudniony w górnictwie (Gärtner, 2019, s. 138).

Po upadku gospodarki centralnie planowanej w Polsce oraz otwarciu się na rynki światowe polski węgiel, który we wcześniejszym okresie niejednokrotnie był wykorzystywany przez władze PRL jako towar w wymianach barterowych z ZSRR za takie towary jak bawełna czy ruda żelaza, stracił na konkurencyjności (Studziński, 1997, s. 173). Okazało się, że polskie kopalnie są w niektórych aspektach zacofane technologicznie. Kosztownym dla budżetu państwa aspektem górnictwa węglowego w Polsce był także uprzywilejowany status pracowników tego sektora gospodarki (m.in. wcześniejsze emerytury, dodatki płacowe), na co po przemianach ustrojowych zabrakło pieniędzy (Bijańska \& Karbownik, 2000, s. 7). Proces restrukturyzacji w Polsce rozpoczął się 30 lat później niż podobny proces w Niemczech.

W Niemczech wraz ze spadkiem konkurencyjności krajowego węgla rząd federalny w 1958 r. podjął decyzję o subsydiowaniu sektora poprzez dopłaty do każdej tony wydobytego węgla kamiennego. Głównym narzędziem tej polityki 
było subsydiowanie niemieckich odbiorców węgla kamiennego (głównie spółki energetyczne oraz stalowe) w celu wyrównania cen węgla krajowego i węgla importowanego. Polityka ta utrzymywała się aż do zamknięcia ostatniej kopalni w zagłębiu w 2018 r. W Polsce proces restrukturyzacji rozpoczął się na początku lat 90. XX w., a subsydiowanie produkcji węgla polegało na bezpośrednim wspieraniu państwowych firm wydobywczych poprzez dotacje w różnej formie od bezpośrednich dopłat dla kopalń, poprzez umarzanie długów firm wydobywczych, np. w Zakładzie Ubezpieczeń Społecznych, aż po odprawy dla pracowników dobrowolnie rezygnujących z pracy.

Edukacja w Zagłębiu Ruhry była jedną ze słabych stron regionu, dlatego też w rozwoju sektora edukacji widziano szansę na dalszy rozwój regionu. W kolejnych latach powstały:

- Uniwersytet Ruhry w Bochum (1962),

- Uniwersytet Techniczny w Dortmundzie (1968),

- Uniwersytet Duisburg-Essen (1972),

- Uniwersytet Witten/Herdecke (1982),

- Uniwersytet w Hagen (1974).

Region, który nie posiadał żadnego uniwersytetu w latach 50. XX w., wraz z końcem procesu restrukturyzacji kształci ok. 270000 studentów oraz posiada 30000 pracowników naukowych, stając się obszarem z dużym zagęszczeniem edukacyjnym i badawczym (Bogumil \& Heinze, 2019, s. 39). Poza uniwersytetami w regionie powstawały również instytuty badawcze oraz parki technologiczne. Natomiast w Zagłębiu Górnośląskim na początku restrukturyzacji istniały już uczelnie wyższe, w tym: Politechnika Śląska w Gliwicach, Uniwersytet Śląski, Akademia Ekonomiczna w Katowicach oraz Śląski Uniwersytet Medyczny w Katowicach. Dzięki temu w procesie restrukturyzacji nie było potrzeby poszerzenia bazy edukacyjnej o nowe podmioty.

W Niemczech główną inwestycją w zakresie górnictwa węgla kamiennego było powołanie w 1968 r. firmy Ruhrkohle AG (obecnie: RAG Aktiengesellschaft), która miała na celu kontrolowane wygaszenie górnictwa w regionie. W skład firmy weszło 25 spółek kontrolujących $80 \%$ wydobycia węgla w Niemczech. Państwo posiadało 27\% udziałów w spółce. Pod koniec lat 60 . XX w. Ruhrkohle AG stała się ogólnokrajową organizacją skupiającą 52 kopalnie węgla, 29 producentów koksu i 5 wytwórni brykietów, zatrudniającą łącznie 182650 pracowników (RAG AG - Company History, 2021). Już w sierpniu 1970 r. firma przyjęła strategię mającą na celu transformację przemysłu wydobywczego w efektywny sektor przemysłowy. Głównymi punktami strategii były: 
- koncentracja na najbardziej efektywnych kopalniach,

- łączenie kopalń jako alternatywa dla zamknięcia podmiotów nierentownych,

- rozłożenie redukcji zatrudnienia w czasie.

Wraz z upływem czasu strategia firmy była zmieniana. Obecnie, po zakończeniu wydobycia, firma zajmuje się odwadnianiem kopalń, oczyszczaniem wód gruntowych oraz rekultywacją terenów pogórniczych.

W Polsce na początku lat 90. XX w. postanowiono podzielić wszystkie kopalnie i utworzyć z nich odrębne jednostki ekonomiczne. W 1993 r. przekazano kopalnie do nowo powstałych spółek (Jastrzębska Spółka Węglowa - JSW, Rybnicka Spółka Węglowa, Bytomska Spółka Węglowa, Nadwiślańska Spółka Węglowa, Rudzka Spółka Węglowa, Gliwicka Spółka Węglowa, Katowicki Holding Węglowy - KHW). Aby wspomóc proces likwidacji kopalń, w 2000 r. powołano Spółkę Restrukturyzacji Kopalń (SRK), która przejmowała i nadal przejmuje przeznaczone do likwidacji kopalnie. Główne cele spółki to likwidacja zakładów wydobywczych oraz zagospodarowanie majątku zlikwidowanych kopalń.

W 2003 r. spółki węglowe (poza KHW i JSW) oraz część zakładów okołogórniczych połączyły się w Kompanię Węglową (KW). Niestety ze względu na brak inwestycji koszty wydobycia w KW wzrosły do tego stopnia, że w 2014 r. tylko 3 na 15 kopalń przynosiły zyski. W związku z trudną sytuacją finansową spółka zbyła kopalnie na rzecz nowo powstałej Polskiej Grupy Górniczej. Niemniej jednak sama KW istnieje do dziś i prowadzi działalność w zakresie turystyki, ubezpieczeń oraz usług na rzecz górnictwa.

Południowy Koncern Węglowy (Tauron Wydobycie S.A.) powstał w 2004 r. i posiada obecnie 3 kopalnie. Tauron Wydobycie S.A. wchodzi w skład grupy Tauron. Jej głównym celem jest dostarczanie węgla dla elektrowni oraz elektrociepłowni należących do grupy. Dodatkowo Tauron Wydobycie S.A. prowadzi sprzedaż węgla w różnych sortymentach dla odbiorców indywidualnych.

Polska Grupa Górnicza (PGG) powstała w 2016 r. i przejęła większość kopalń oraz zakładów należących do Kompanii Węglowej. Główną przyczyną powstania PGG było przejęcie majątku oraz zobowiązań bankrutującej KW. W 2017 r. PGG przejęła także kopalnie należące do KHW. Obecnie PGG jest największym producentem węgla kamiennego w Europie.

Ze wszystkich spółek węglowych w Polsce Jastrzębska Spółka Węglowa przetrwała w całości od 1993 r. do teraz. Działania JSW bardzo przypominają w niektórych aspektach działania Ruhrkohle AG. Podobnie jak niemiecka spółka, JSW promuje nowe technologie i działa nie tylko w branży wydobywczej, 
ale także przetwórczej, wprowadzając na rynek nowe produkty oraz nowe technologie. Jednak to działanie wynika głównie z faktu, że w kopalniach JSW wydobywany jest węgiel koksujący potrzebny w przemyśle hutniczym, który na rynkach światowych jest dużo droższy niż węgiel energetyczny (Ozga-Blaschke, 2009). W przypadku procesów przekształceń samych kopalń niemieckie podejście wydaje się bardziej spójne oraz zorganizowane, ponieważ ciągłe tworzenie nowych podmiotów generuje problemy natury organizacyjnej, marnując tym samym środki finansowe i czas. Należy również zaznaczyć, że kopalnie zorganizowane poza JSW od lat 90 . XX w. borykały się z problemami finansowymi. W porównaniu do działań niemieckich w Polsce nie koncentrowano się na kopalniach, które przynosiły zyski, tylko za wszelką cenę dążono do ratowania większości zakładów.

Mocną stroną Zagłębia Ruhry jest jego położenie oraz rozwinięta infrastruktura. Istniejąca tam sieć drogowa tworzy jedną z najbardziej rozbudowanych tego typu sieci drogowych w Europie. Połączenie autostradowe z resztą kraju oraz Francją i Holandią czyni ten region dobrym miejscem dla inwestycji. Natomiast w Zagłębiu Górnośląskim sieć drogowa na początku transformacji nie była tak rozwinięta, jak w Zagłębiu Ruhry, jednak od lat 90. XX w. jest ona ciągle dynamicznie rozbudowywana. Rola regionu ze względu na infrastrukturę drogową wzrosła szczególnie po wybudowaniu autostrad A4 i A1, co pozwoliło na połączenie regionu z resztą kraju oraz Republiką Czeską - ważnym polskim partnerem handlowym.

Znaczącym elementem infrastruktury w Zagłębiu Ruhry pozostaje żegluga śródlądowa. Żaden inny środek transportu nie przewozi tylu towarów, korzystając $\mathrm{z}$ tak niewielkiej ilości energii. W związku z zapotrzebowaniem przemysłu węglowego i stalowego oraz górnictwa węgla kamiennego w XIX i XX wieku w Zagłębiu Ruhry powstał jeden z najgęstszych systemów kanałów i portów śródlądowych w Europie, z którego obecnie korzystają także nowoczesne przedsiębiorstwa logistyczne. Dzięki Renowi Zagłębie Ruhry posiada bardzo dobre, opłacalne ekonomicznie połączenie z portami w Amsterdamie, Rotterdamie oraz Antwerpii. W Zagłębiu Górnośląskim pomimo znacznej odległości do portów żegluga śródlądowa nie jest wykluczona. Odra stwarza dogodne warunki do żeglugi dzięki Kanałowi Gliwickiemu i portowi w Gliwicach, z którego szlak wodny biegnie aż do portu w Szczecinie. Niestety wieloletnie zaniedbania doprowadziły do marginalizacji tego ekologicznego i ekonomicznie opłacalnego środka transportu (Skupień et al., 2016). Warto w tym miejscu wspomnieć, iż Odrzańska Droga Wodna łącząca Morze Bałtyckie w Świnoujściu z Dunajem 
w Bratysławie została wpisana w 2017 r. do sieci dróg wodnych o międzynarodowym znaczeniu. Z chwilą ratyfikacji opracowanego przez ONZ Europejskiego Porozumienia w Sprawie Głównych Śródlądowych Dróg Wodnych o Międzynarodowym Znaczeniu (Konwencja AGN) Polska zobowiązała się do przywrócenia żeglowności i zapewnienia co najmniej IV klasy żeglowności (najniższa klasa międzynarodowa) m.in. dla szlaku Gliwice-Szczecin.

Oba regiony wraz z kryzysem związanym z wydobyciem węgla były zmuszone do rozwijania nowych gałęzi przemysłu. W Zagłębiu Ruhry skupiono się na nowych technologiach, w szczególności tych związanych z ochroną środowiska, energią odnawialną oraz przemysłem motoryzacyjnym. W mieście Bochum w 1962 r. została otwarta fabryka General Motors, która w kolejnych latach przekazała część produkcji do powstałej w 1998 r. fabryki GM w Gliwicach. W kolejnych latach postępujące procesy globalizacji przyczyniły się do zamknięcia fabryki w Bochum. W przyszłości dla obu regionów szansą na rozwój może stać się rosnące zainteresowanie samochodami elektrycznymi oraz hybrydowymi, do których wyprodukowania potrzeba nowych komponentów, wcześniej niewytwarzanych na tak dużą skalę, takich jak akumulatory elektryczne i silniki elektryczne. Regiony z elektrowniami węglowymi posiadają potencjał przyciągania firm zajmujących się energią odnawialną z powodu wysokich kompetencji w branży energetycznej, historycznej identyfikacji z instalacjami energetycznymi, a także posiadania odpowiednej instalacji wysokonapięciowej. Polityka związana z ochroną środowiska została wprowadzona w Zagłębiu Ruhry w latach 70. XX w., kiedy to $\mathrm{z}$ powodu zaostrzenia norm środowiskowych z przemysłu węglowego i stalowego powstał sektor ochrony środowiska. Jest on nadal obecny w regionie, chociaż przemysł węglowy i stalowy już nie istnieją. Podobne normy związane z ochroną środowiska zostały wprowadzone w Zagłębiu Górnośląskim, kwestie środowiskowe nabrały szczególnego znaczenia wraz z wejściem Polski w struktury Unii Europejskiej. W ostatnim czasie w Zagłębiu Górnośląskim dzięki promowaniu ochrony środowiska powstało wiele firm zajmujących się m.in. fotowoltaiką oraz czystymi technologiami węglowymi, co oznacza cały łańcuch od wydobycia węgla aż do utylizacji odpadów. Przykłady takich technologii to zgazowanie węgla lub technologie usuwania dwutlenku węgla (Marcisz et al., 2017).

Niestety w obu regionach na początku transformacji firmy związane z przemysłem węglowym starały się blokować zmiany strukturalne, szczególnie na wczesnym etapie restrukturyzacji. Głównym powodem takich działań były dotacje dla sektora węglowego, dzięki którym firmy związane z górnictwem węgla 
mogły liczyć na zwiększone zyski. Dodatkowo w Niemczech przez długi czas znaczna część terenów górniczych należących do firm wydobywczych pozostawała opuszczona, gdyż firmy te odmawiały udostępnienia tych terenów, blokując tym samym możliwość pojawiania się nowych firm w regionie, tym samym aktywnie hamując dalszy rozwój regionu (Gärtner, 2019, s. 140). W Polsce ta blokada wynikała $z$ innych przyczyn, takich jak niechęć branży do zmian czy brak chęci przekwalifikowania się przez pracowników górnictwa. Innym problemem istotnym z punktu widzenia przyszłych inwestycji, głównie przemysłowych na terenach pogórniczych, na których nadal odbywa się eksploatacja, jest aktywność górotworu oraz szkody górnicze, co widać na przykładzie inwestycji w województwie śląskim (Frankowski, Mazurkiewicz, \& Krzysztofik, 2020, s. 11).

Duże znaczenie w procesie restrukturyzacji regionów ma wsparcie małych i średnich przedsiębiorstw. Dotacje, programy pomocowe czy tworzenie stref przemysłowych dodatkowo podnoszą atrakcyjność regionu w oczach zagranicznych inwestorów. Niestety w obu omawianych regionach panował tradycyjny model rodziny, czyli mężczyzny jako jedynego żywiciela rodziny, przez co poziom przedsiębiorczości wśród mieszkańców był niższy niż w innych regionach (Frankowski, Mazurkiewicz, Sokołowski et al., 2020, s. 15) i dlatego też w zakresie wsparcia przedsiębiorczości ważną rolę odgrywa edukacja.

\section{Wyniki badań}

Przeprowadzona na potrzeby badań kwerenda literatury oraz analiza dostępnych danych wskazuje na znaczne podobieństwo między omawianymi regionami $\mathrm{w}$ momencie rozpoczęcia procesów restrukturyzacji. Wybór metod i narzędzi tego procesu w obu przypadkach był uzasadniony bieżącą sytuacją w regionie oraz bieżącą sytuacją na światowym rynku węgla. Porównując oba omawiane procesy restrukturyzacyjne, można zauważyć, że proces przeprowadzony w Zagłębiu Ruhry miał charakter długookresowy i w omawianym okresie był konsekwentnie realizowany. Natomiast proces trwający w Zagłębiu Górnośląskim cechuje duża zmienność wynikająca z nacisków społecznych i politycznych, a także ze zmian na globalnym rynku węgla i surowców energetycznych.

Do najbardziej istotnych pozytywnych efektów restrukturyzacji w Zagłębiu Ruhry można zaliczyć rozbudowę sektora edukacji, w którym wcześniej szkolnictwo wyższe nie istniało, oraz rozwój przemysłu niezwiązanego z sektorem górniczym. Jednak pomimo znacznych sukcesów i zakończenia procesu restrukturyzacji górnictwa węgla kamiennego w tym regionie (ostatnia kopalnia została 
zamknięta) nadal istnieją problemy związane z sektorem górnictwa węgla kamiennego, które wymagają dalszych rozwiązań o charakterze instytucjonalnym. Do głównych problemów związanych z górnictwem, a odczuwanych przez region, zaliczyć należy m.in. dużą ilość nieużytków poprzemysłowych, takich jak puste hale przemysłowe czy tereny pokopalniane, które trzeba stopniowo rewitalizować.

Koniec procesu restrukturyzacji górnictwa węgla kamiennego w Polsce nadal jest trudny do przewidzenia ze względu na duże zróżnicowanie kolejnych programów i brak koncepcji przewodniej dla wszystkich kolejnych planów. Realizowany obecnie program obejmuje już zamknięcie ostatniej kopalni węgla energetycznego, jednak dotychczasowe doświadczenia dotyczące poprzednich programów wywołują wątpliwości odnośnie do jego całościowej realizacji.

Skutki restrukturyzacji w Zagłębiach Ruhry oraz Górnośląskim przedstawiono w tabeli 3.

Tabela 3. Skutki restrukturyzacji w Zagłębiu Ruhry i Zagłębiu Górnośląskim

\begin{tabular}{|l|c|c|}
\hline \multicolumn{1}{|c|}{ Skutek } & Zaglębie Ruhry & Zaglębie Górnośląskie \\
\hline zamknięcie dużej liczby nierentownych kopalń & $\mathbf{X}$ & $\mathbf{X}$ \\
\hline rozwój sektora edukacji & $\mathbf{X}$ & $\mathbf{X}$ \\
\hline $\begin{array}{l}\text { znaczący wzrost bezrobocia spowodowany } \\
\text { procesami restrukturyzacyjnymi }\end{array}$ & $\mathbf{X}$ & $\mathbf{X}$ \\
\hline $\begin{array}{l}\text { rozwój sektorów niezwiązanych z górnictwem } \\
\text { węgla kamiennego }\end{array}$ & $\mathbf{X}$ & w trakcie \\
\hline rozwój infrastruktury & $\mathbf{X}$ & w trakcie \\
\hline scalenie kopalń węgla kamiennego & $\mathbf{X}$ & w trakcie \\
\hline rozwój żeglugi śródlądowej & $\mathbf{X}$ & w trakcie \\
\hline
\end{tabular}

Źródło: Opracowanie własne.

\section{Dyskusja i wnioski}

Procesy restrukturyzacyjne w regionach silnie związanych z górnictwem to bardzo ciekawy obszar badawczy ze względu na złożoność oraz skutki tych procesów. Mnogość czynników kulturowych, społecznych i ekonomicznych wpływających na procesy restrukturyzacyjne sprawia, że zagadnienie można badać poprzez różne aspekty i w odmienny sposób oceniać ich efektywność. Można się pochylić nad podobnymi procesami w innych regionach, np. we Francji czy Belgii, i dzięki analizie porównawczej wskazać te, które miałyby zastosowanie w podobnym procesie w Polsce.

W artykule skoncentrowano się na porównaniu procesów restrukturyzacyjnych w dwóch podobnych regionach. Starano się wykazać, że pomimo różnic 
w działaniach, skutki procesów restrukturyzacyjnych są podobne, czyli zamknięto dużą liczbę kopalń, nastąpił rozwój infrastruktury oraz przemysłu, ale także zaobserwowano wzrost bezrobocia. Procesy restrukturyzacyjne całych sektorów gospodarki są wielką szansą dla regionów i mogą stanowić impuls dla rozwoju, jednak niosą za sobą też zagrożenia, szczególnie dla społeczności, na którą zmiany mają istotny wpływ.

Mateusz Rybarz - student Szkoły Doktorskiej na Uniwersytecie Ekonomicznym w Katowicach (ekonomia i finanse)

\section{Spis literatury}

Alves Dias, P., Kanellopoulos, K., Medarac, H., Kapetaki, Z., Miranda-Barbosa, E., Shortall, R., Czako, V., Telsnig, T., Vazquez-Hernandez, C., Lacal Arántegui, R., Nijs, W., Gonzalez Aparicio, I., Trombetti, M., Mandras, G., Peteves, E., \& Tzimas, E. (2018). EU coal regions: Opportunities and challenges ahead. European Commission, Joint Research Centre, The Netherlands. https://doi.org/10.2760/ 668092

Bijańska, J., \& Karbownik, A. (2000). Restrukturyzacja polskiego górnictwa wegla kamiennego w latach 1990-1999. Gliwice: Wydawnictwo Politechniki Śląskiej.

Bogumil, J., \& Heinze, R. G. (2019). Von der Industrieregion zur Wissensregion. Strukturwandel im Ruhrgebiet. Aus Politik und Zeitgeschichte, 69, 1/3, 39-46.

Borowiecki, R. (2014). Zarzadzanie restrukturyzacja przedsiębiorstw i gospodarki. Kraków: Fundacja Uniwersytetu Ekonomicznego w Krakowie.

Diagnoza systemu transportu województwa śląskiego. (2012). Katowice: Wydział Planowania Strategicznego i Przestrzennego Urzędu Marszałkowskiego Województwa Śląskiego.

Frankowski, J., Mazurkiewicz, J., \& Krzysztofik, R. (2020). Województwo śląskie w punkcie zwrotnym transformacji (IBS Research Report 02/2020). Instytut Badań Strukturalnych.

Frankowski, J., Mazurkiewicz, J., Sokołowski, J., \& Lewandowski, P. (2020). Zatrudnienie $w$ górnictwie węgla kamiennego w Zaglębiu Górnoślaskim (IBS Research Report 01/2020). Instytut Badań Strukturalnych.

Galgóczi, B. (2019). Introductory overview two faces of (a) just transition: The coal story and the car story. W: B. Galgóczi (Ed.), Towards a just transition: Coal, cars and the world of work (pp. 7-29). Brussels: The European Trade Union Institute.

Gärtner, S. (2019). An attempt at preventive action in the transformation of coal-mining regions in Germany. W: B. Galgóczi (Ed.), Towards a just transition: Coal, cars and the world of work (pp. 135-154). Brussels: The European Trade Union Institute. 
Grynchyshyn, J. (2015). Restrukturyzacja jako narzędzie zarządzania antykryzysowego przedsiębiorstw. Zeszyty Naukowe Uniwersytetu Przyrodniczo-Humanistycznego w Siedlcach, 106, 49-61.

Jureczka, J., \& Nowak, G. J. (2016). Polskie zagłębia węgla kamiennego - przegląd informacji i badań geologicznych. Przegląd Geologiczny, 64(9), 617-630.

Kuchciński, J. (1958). Geologiczne zasoby węgla Górnośląskiego Zagłębia Węglowego na tle mapy węglonośności. Geological Quarterly, 2(3), 553-564.

Marcisz, M., Probierz, K., Chmielniak, T., \& Sobolewski, A. (2017). Czyste technologie węglowe - szansą rozwoju sektora górniczego. Systemy Wspomagania w Inżynierii Produkcji, 6(3), 121-135.

Oei, P.-Y., Brauers, H., \& Herpich, P. (2020). Lessons from Germany's hard coal mining phase-out: Policies and transition from 1950 to 2018. Climate Policy, 20(8), 963-979. https://doi.org/10.1080/14693062.2019.1688636

Ozga-Blaschke, U. (2009). Relacje cen węgli energetycznych i koksowych na rynkach międzynarodowych. Polityka Energetyczna, 12, 453-463.

Popkiewicz, M. (2021). Obrazek dnia: Wydobycie węla w Polsce. Pobrano z: https:// ziemianarozdrozu.pl/artykul/3777/obrazek-dnia-wydobycie-wegla-w-polsce (dostęp: 19.04.2021).

Pudlik, M., \& Garus, C. (2009). Jak feniks z popiołów: Rozwój struktur metropolitalnych w Zagłębiu Ruhry jako wzór dla rozwoju Górnego Śląska? Studia Regionalne $i$ Lokalne, 1(35), 32-51.

RAG AG - Company History. (2021). Pobrano z: https://www.company-histories.com/ RAG-AG-Company-History.html (dostęp: 19.04.2021).

Skupień, E., Kuciaba, E., \& Gąsior, A. (2016). Perspektywy rozwoju żeglugi śródlądowej w Polsce w latach 2016-2030. Zeszyty Naukowe Akademii Morskiej w Gdyni, 97, 111-120.

Statistik der Kohlenwirtschaft E.V. (2019) Der Kohlebergbau in der Energiewirtschaft der Bundesrepublik Deutschland im Jahre 2018. Pobrano z: https://kohlenstatistik.de/ wp-content/uploads/2019/10/Kohlenwirt_Silberheft_final.pdf (dostęp: 19.04.2021).

Studziński, R. (1997). Ekonomiczne struktury podległości Polski wobec ZSRR: problemy badawcze i interpretacyjne ze szczególnym uwzględnieniem lat 1944-1957. Acta Universitatis Nicolai Copernici, 30(322), 163-181.

Żaba-Nieroda, R. (2018). Restrukturyzacja organizacyjna i finansowa polskiego sektora przemysłu obronnego. W: J. Famielec, M. Kożuch (red.), Restrukturyzacja sektorów gospodarki i przedsiębiorstw. Wybrane zagadnienia (s. 49-75). Kraków: Fundacja Uniwersytetu Ekonomicznego w Krakowie. 


\title{
Strategic investments in restructuring processes in the Upper Silesia and the Ruhr District
}

\begin{abstract}
The main aims of the paper are: to indicate the similarities and differences between the Ruhr District and the Upper Silesia occurring during the restructuring of these mining regions and to indicate investments of strategic importance directly related to the processes carried out. For the research, a detailed review of the available literature on the subject (both in Polish, English, and German) was made and the analysis of statistical data was used. The paper discusses the similarities of both regions at the start of the process and the significant differences in the time of restructuring. The process implemented in the Ruhr District was a well-thought-out, consistently implemented, long-term strategy, therefore its effects are assessed positively, both in the social and economic context. On the other hand, the solutions adopted in the Upper Silesia are characterized by the variability of the concept and the chaotic nature of the solutions implemented. Nevertheless, there are strengths and weaknesses in this process in both regions.
\end{abstract}

Keywords: mining, restructuring, hard coal, Upper Silesia, Ruhr District.

JEL Classification: O170, R110, L690. 